Adv Chronic Kidney Dis. 2011 March ; 18(2): 113-119. doi:10.1053/j.ackd.2010.12.003.

\title{
Phosphate and Cardiovascular Disease
}

\author{
Jessica Kendrick, MD¹, Brian Kestenbaum, MD², and Michel Chonchol, MD1 \\ ${ }^{1}$ University of Colorado Denver Health Sciences Center, Aurora, CO, USA \\ ${ }^{2}$ University of Washington, Division of Nephrology and Kidney Research Institute; Seattle, WA, \\ USA
}

\begin{abstract}
Hyperphosphatemia is a major risk factor for death, cardiovascular events and vascular calcification among patients with and without kidney disease. Even serum phosphate levels within the "normal laboratory range" associate with a greater risk of death and cardiovascular events. Potential mechanisms by which increased phosphate results in adverse outcomes are incompletely understood but current evidence suggests a direct effect of phosphate on vascular calcification and modulation of key hormones fibroblast growth factor-23 and calcitriol. Despite convincing epidemiologic connections between phosphate excess and cardiovascular disease, no clinical trials have been conducted to establish a causal relationship and large, randomized trials with hard endpoints are urgently needed to prove or disprove the benefits and risks of therapy.
\end{abstract}

\section{Introduction}

Phosphorus is an essential mineral that regulates multiple metabolic processes, including signal transduction, energy production and mineral metabolism. ${ }^{1}$ Serum phosphorus concentrations are tightly regulated in healthy individuals through several mechanisms including dietary absorption, bone flux and renal excretion. It is known that overt hyperphosphatemia results in adverse effects on bone and parathyroid glands. ${ }^{2,3}$ Over the past several years, higher serum phosphate concentrations have been found to associate with death, cardiovascular events and vascular calcification in human studies of both the general population and chronic kidney disease (CKD) ${ }^{4-9}$ This mounting evidence suggests the possibility that lowering serum phosphate levels could reduce cardiovascular outcomes and thus may be a future target of cardiovascular disease management. This review summarizes the major clinical and experimental evidence supporting the role of disordered phosphate metabolism in cardiovascular disease and reviews potential mechanisms and recommendations for treatment of serum phosphate in CKD patients.

\section{Overview of Phosphate Homeostasis}

In healthy adults, the steady-state serum phosphorus concentration is determined by the balance between the intestinal absorption of phosphate from the diet, the storage and release

Corresponding author's address: Jessica Kendrick, MD: Assistant Professor, Division of Renal Diseases and Hypertension, University of Colorado, Denver, CO 80262, USA. Phone: 303-436-5905; Fax: 303-436-3509; Jessica.Kendrick@ucdenver.edu. 
of phosphate in bone, and the excretion of phosphate through the urine. The key hormonal regulators of phosphate metabolism include 1,25-dihydroxyvitamin $\mathrm{D}$ (calcitriol), parathyroid hormone (PTH) and fibroblast growth factor-23 (FGF-23). Approximately $60-70 \%$ of dietary phosphorus is absorbed in the intestine mainly, via an active sodium/ phosphate $(\mathrm{Na} / \mathrm{Pi})$ cotransport. ${ }^{10}$ Calcitriol stimulates gastrointestinal $\mathrm{Na} / \mathrm{Pi}$ cotransport thereby increasing phosphate absorption, but only $30 \%$ of intestinal absorption is directly regulated by calcitriol. ${ }^{11}$ Thus, the kidneys play a major role in controlling phosphate homeostasis.

Normally, the amount of phosphate excreted in the urine is equal to that absorbed from the intestine. PTH is a polypeptide secreted from the parathyroid glands resulting in decreased reabsorption of phosphate in the proximal tubule by decreasing the activity and number of $\mathrm{Na} / \mathrm{Pi}$ cotransporters. ${ }^{10} \mathrm{PTH}$ also stimulates bone resorption which can result in an increase in serum phosphate. However, in patients with normal renal function, PTH tends to lower serum phosphate concentration as the urinary effect of PTH predominates. FGF-23 is produced by osteocytes and has been identified as the main phosphaturic hormone responsible for regulating serum phosphate. ${ }^{12}$ FGF-23 inhibits renal phosphate reabsorption and calcitriol synthesis through inhibition of 1-a- hydroxylase, thus increasing urinary phosphate excretion and decreasing phosphate reabsorption in the intestine. ${ }^{12}$ FGF-23 weakly binds its receptor (FGFR-1c) and thus requires a co-factor, which is klotho, for activity. FGF-23 is presumed to be active only in tissues that can also manufacture klotho (distal tubule of kidney, parathyroid glands, brain).

\section{Metabolism of Phosphate in Chronic Kidney Disease}

In patients with advanced kidney disease, hyperphosphatemia results from a decrease in functioning nephrons. With the initial fall in glomerular filtration rate (GFR) there is a decrease in the amount of filtered phosphate and subsequently excreted phosphate. This leads to an increase in ultrafiltered phosphate by the remaining nephrons and an increase in single nephron phosphate excretion, presumably due to the rise in serum concentrations of PTH and FGF-23. FGF-23 levels and PTH rise early in the course of kidney disease long before overt hyperphosphatemia occurs, and FGF-23 rises earlier than PTH. ${ }^{13}$ The increase in FGF-23 and PTH result in decreased tubular reabsorption of phosphate and the fractional excretion of phosphate can reach as high as $90 \%$. Thus, serum phosphate is maintained within normal limits until the GFR falls to less than approximately $35 \mathrm{~mL} / \mathrm{min}$. In patients with anuric end-stage renal disease the increase in serum phosphate results not only from decreased phosphate excretion but also from an increase in bone release of phosphate that occurs in response to chronically elevated PTH levels. ${ }^{10}$ Importantly, in-vitro, animal, and human studies have thus far failed to convincingly demonstrate that phosphate excess can trigger FGF-23 secretion, creating an important knowledge gap in this area. A recent study in pre-dialysis CKD patients found that neither the use of phosphate binders nor a low phosphate diet reduced serum FGF-23 levels despite lowering 24 hour urinary phosphate excretion. ${ }^{14}$ 


\section{Serum Phosphate Levels and Outcomes}

Higher serum phosphate levels consistently associate with clinical and sub-clinical cardiovascular disease among patients with and without kidney disease.

\section{Phosphate and vascular calcification and stiffness}

Vascular calcification is a risk factor for cardiovascular events and mortality in both CKD and non-CKD populations. ${ }^{15-20}$ Calcium phosphate deposition is the hallmark of vascular calcification and is found in specific layers of blood vessels. ${ }^{21}$ Intimal calcification is found in atherosclerotic disease, whereas medial calcification is found in arteriosclerotic lesions. ${ }^{22-24}$ Hyperphosphatemia has been shown to be linked to arterial calcifications in cell culture models and in several human observational studies. In one small study of chronic dialysis patients, those with vascular calcifications had higher serum phosphate levels than patients without calcifications. ${ }^{25}$ Among individuals who have CKD and are not yet on dialysis, higher serum phosphate concentrations associate with vascular and cardiac valve calcification. In 439 participants from the Multi-Ethnic Study of Atherosclerosis with moderate CKD (mean estimated GFR $51 \mathrm{ml} / \mathrm{min}$ ) and no clinical CVD, each $1 \mathrm{mg} / \mathrm{dL}$ increase in serum phosphate was associated with a $21 \%(\mathrm{p}=0.002), 33 \%(\mathrm{p}=0.001), 25 \%$ $(\mathrm{p}=0.16)$ and $62 \%(\mathrm{p}=0.007)$ greater prevalence of coronary artery, thoracic, aortic and mitral valve calcification, respectively after adjustment for demographics and estimated GFR. ${ }^{26}$ Higher serum phosphate is also linked to vascular stiffness in people with moderate CKD. In a study of subjects with moderate CKD from the Multi-Ethnic Study of Atherosclerosis, a serum phosphate level greater than $4.0 \mathrm{mg} / \mathrm{dL}$ was associated with a 4fold greater risk of high ankle-brachial index (ABI), a hallmark of peripheral arterial stiffness, compared to a phosphate level less than $3.0 \mathrm{mg} / \mathrm{dL}$ (RR 4.6, 95\% CI 1.6 to 13.2, $\mathrm{p}=0.01) .^{27}$

The relationship between serum phosphate and vascular calcification has also been evaluated in the general population. In 3015 individuals from the Coronary Artery Risk Development in Young Adults (CARDIA) ${ }^{28}$ study, subjects with serum phosphate levels greater than $3.9 \mathrm{mg} / \mathrm{dL}$ had a $52 \%$ greater risk of coronary artery calcification 15 years later, as compared to those with a phosphate level less than $3.3 \mathrm{mg} / \mathrm{dL}$ (adjusted OR 1.52, 95\% CI 1.04 to 2.22). High serum phosphate concentrations also associate with vascular stiffness in the general population. The relationship between ABI and serum phosphate was examined in 581 participants from the National Health and Nutrition Examination Survey with normal renal function. Subjects who had serum phosphate concentrations in the highest quartile (3.7-5 mg/dL) had almost a five-fold increased risk of high ABI compared to subjects with serum phosphate in the lowest quartile $(3.1-3.4 \mathrm{mg} / \mathrm{dL})$ after multivariate adjustment (adjusted OR 4.78, 95\% CI 1.73 to $13.2, \mathrm{p}=0.003$ ). ${ }^{29}$

The findings from studies in pre-dialysis patients and patients without CKD suggest that higher serum phosphate levels even within the "normal laboratory range" $(<4.5 \mathrm{mg} / \mathrm{dL})$ are a risk factor for vascular calcification. Many of these studies were conducted in established cardiovascular health studies that included quality measurement of major cardiovascular risk factors and other important confounding factors. However, it remains possible that observed associations are due to unmeasured factors that associate with both higher serum phosphate 
concentrations and cardiovascular disease. Randomized trials using agents that reduce phosphate are needed to prove a causal relationship. To date, no randomized trials have compared phosphate binding agents with placebo in order to evaluate whether targeting phosphate metabolism reduce or prevent vascular calcification.

\section{Phosphate and Cardiovascular Disease}

Patients with CKD have a reduced lifespan, and the majority of these patients die from cardiovascular diseases. Left ventricular hypertrophy is a known risk factor for cardiovascular events (CVE) and mortality in patients with and without CKD and is highly prevalent in the CKD population. ${ }^{30-32}$ In fact, almost $70 \%$ of dialysis patients have LVH. ${ }^{33}$ Higher serum phosphate concentrations associate with LVH in dialysis patients, independent of calcification. ${ }^{33,34}$ Moreover, intensive dialysis, which is highly effective at reducing serum phosphate concentrations, decreases LVH in the setting of chronic dialysis. ${ }^{35}$ However, to date, no randomized trials have been performed evaluating the effect of phosphorus control on LVH.

Higher serum phosphate concentrations associate with cardiovascular events in numerous studies in both the general and CKD populations. In a study of over 14,000 hemodialysis patients, the fully adjusted risk of cardiovascular events was progressively greater with incrementally higher serum phosphate concentrations. Subjects whose serum phosphate concentrations were in the highest quintile had a $25 \%$ greater risk of cardiovascular events compared to those in the lowest quintile. ${ }^{36}$ Block et al. ${ }^{37}$ reported a linear association of higher serum phosphate concentrations with a greater risk of cardiovascular hospitalizations in a national cohort of 40,538 hemodialysis patients. In CKD patients, not yet on dialysis, serum phosphate is also associated with cardiovascular events. In a study of 3,490 veterans who had stage III-IV CKD (estimated GFR $45 \mathrm{~mL} / \mathrm{min}$ ), each 1 unit higher serum phosphate concentration was associated with a 35\% greater risk for acute MI (HR 1.35, 95\% CI 1.09 to 1.66) after adjustment for traditional cardiovascular risk factors and estimated kidney function. ${ }^{7}$

Associations of higher serum phosphate concentrations with cardiovascular disease now extend to individuals who do not have apparent kidney disease. ${ }^{4,5,38}$ Dhingra et al. ${ }^{5}$ prospectively evaluated 3,368 participants from the Framingham Offspring Study who were free of clinical CVD and had an estimated GFR $\geq 60 \mathrm{ml} / \mathrm{min}$ at baseline. After a mean duration of follow-up of 16 years, serum phosphate levels greater than $3.5 \mathrm{mg} / \mathrm{dL}$ were associated with an estimated 55\% greater risk of incident CVD compared to levels less or equal than $2.8 \mathrm{mg} / \mathrm{dL}$ (HR 1.55, 95\% CI 1.16 to 2.07). Similar findings were reported from a post-hoc analysis of the Cholesterol and Recurrent Events Study (CARE) which included 4,159 participants with known coronary artery disease and a mean eGFR $>60 \mathrm{~mL} / \mathrm{min}^{4}{ }^{4} \mathrm{In}$ the CARE study, a baseline serum phosphate level greater than $4.0 \mathrm{mg} / \mathrm{dL}$ was associated with an estimated 50\% greater risk of myocardial infarction (95\% confidence interval 5\% to $116 \%$ greater) and a $43 \%$ greater risk of new-onset heart failure (95\% confidence interval $5 \%$ lower to $114 \%$ greater), compared to serum phosphate levels of 2.5 to $3.4 \mathrm{mg} / \mathrm{dL}$. 


\section{Phosphate and Mortality}

Given associations of serum phosphate with cardiovascular events, it is not surprising that

higher serum phosphate concentrations also associate with all-cause mortality in the general and CKD populations. In the first study to identify potential health consequences of hyperphosphatemia, Block et reported an estimated $27 \%$ greater risk of total mortality associated with serum phosphate concentrations greater than $6.5 \mathrm{mg} / \mathrm{dL}$ among 6,500 chronic dialysis patients. ${ }^{8}$ These associations have been replicated in several other studies of chronic dialysis patients, ${ }^{37,39,40}$ and similar findings have been reported in patients with predialysis CKD. ${ }^{7,41}$ For example, each $1 \mathrm{mg} / \mathrm{dL}$ higher serum phosphate concentrations was associated with a $23 \%$ greater adjusted risk of all-cause mortality (95\% CI $12 \%$ to $36 \%$ greater) among 3,490 veterans who had stage III-IV CKD. ${ }^{7}$ In another study of patients with advanced CKD who were not yet on dialysis, each $1 \mathrm{mg} /$ higher serum phosphate concentration was associated with a $62 \%$ greater risk of total mortality after adjustment for co-morbid conditions (adjusted RR 1.62, 95\% CI 1.02 to 2.59). ${ }^{41}$ Among participants in the CARE clinical trial, Tonelli et al. found a graded, independent association of higher baseline serum phosphate concentrations with all-cause mortality. ${ }^{4}$ Study participants who had a baseline serum phosphate level greater than or equal to $3.5 \mathrm{mg} / \mathrm{dL}$ had an estimated $27 \%$ greater adjusted risk of death (95\% CI $2 \%$ to $59 \%$ greater) compared to those who had a serum phosphate level less than $3.5 \mathrm{mg} / \mathrm{dL}$.

In aggregate, these studies show associations of even subtly higher serum phosphate levels within the normal laboratory range with all cause mortality. If these associations are found to represent a causal relationship, it is possible that phosphate reduction strategies could reduce the risk of death among patients who have high-normal serum phosphate concentrations.

\section{Mechanisms}

Two candidate mechanisms by which serum phosphorus could contribute to cardiovascular disease are vascular calcification and modulation of circulating serum hormones, specifically PTH, FGF-23, and calcitriol.

\section{Phosphate and Vascular Calcification}

Cell culture and in-vivo animal models demonstrate a pivotal role for phosphate in vascular calcification. Vascular calcification is a highly regulated process in which vascular smooth muscle cells (VSMC) express and deposit bone-associated, mineralization-regulating proteins whose function in the vasculature is to actively inhibit calcification through regulating vascular smooth muscle cell (VSMC) phenotype and/or inhibiting hydroxyapatite crystal growth. ${ }^{42,43}$ In medial calcification, VSMCs lose expression of calcification inhibitors, such as matrix gla protein, and express differentiation markers of osteoblasts (Cbfa-1), such as osteocalcin and chondrocytes. ${ }^{44}$ In vitro, phosphorus directly induces phenotypic changes in VSMCs by increasing gene transcription of proteins involved in matrix mineralization and bone formation, and simultaneously down-regulating transcription factors for smooth muscle cells, suggesting that phosphorous is sufficient for causing transformation into an osteochondrogenic phenotype. ${ }^{45,46}$ Studies have found that the 
VSMC calcification is induced in a dose and time dependent manner when phosphate levels are increased in vitro. ${ }^{47,48}$ This phenotypic change occurs through a mechanism that requires sodium-dependent phosphate cotransporters. Type III Na/Pi cotransporters, specifically Pit-1, have been characterized in VSMC ${ }^{49}$ Phosphate enters the VSMC through the Pit-1 cotransporter and induces an osteochondrogenic phenotype change. ${ }^{49}$ Treatment of VSMCs in vitro with an inhibitor of the Na/Pi cotransporter results in decreased phosphate uptake, calcification and osteochonodrogenic phenotype in the VSMC. ${ }^{47,50,51}$ Furthermore, the expression of osteogenic differentiation markers Runx2 and osteopontin are blocked in VSMC that have been transduced with Pit-1 knockdown cells in vitro. ${ }^{52}$ In vivo, Mizobuchi et al. ${ }^{53}$ showed that Pit- 1 mRNA levels were increased in calcified aortas of rats with renal failure and severe secondary hyperparathyroidism whereas no calcification was found in aortas of control animals. El-Abbadi et al. showed that feeding CKD animals a normal phosphate diet lead to diffuse medial calcification whereas feeding CKD animals a low phosphate diet did not. ${ }^{54}$ These in vitro and animal experimental results demonstrate that phosphate and the Pit-1 cotransporter on VSMCs plays key roles in controlling vascular calcification. It is currently unknown whether $\mathrm{Na} / \mathrm{Pi}$ cotransporters play a role in vascular calcification in human disease.

\section{Phosphate and Vitamin D}

Several prospective, population-based cohort studies have found low vitamin D levels to associate with CVD. ${ }^{55,56}$ Activated vitamin $\mathrm{D}$ (calcitriol) potently suppresses the reninangiotensin-aldosterone system and regulates cardiomyocyte proliferation and hypertrophy. ${ }^{55,56} \mathrm{~A}$ second possible mechanism by which phosphate may influence CVD risk is by inhibiting the activation of vitamin D. As discussed earlier, FGF-23 is a central hormone for controlling phosphorus homeostasis by increasing renal phosphate excretion. FGF-23 also potently inhibits 1-a-hydroxylase activity in the kidney thereby decreasing 1,25-dihydroxyvitamin D (calcitriol) synthesis. Knockout animals deficient in FGF-23 have 10-fold higher circulating calcitriol levels compared to normal controls. Thus, serum phosphate may suppress calcitriol levels via signaling FGF-23, though it should be noted that no studies have yet conclusively demonstrated a direct signal between phosphate excess and FGF-23. In the general population, serum phosphate may also have a direct effect on calcitriol synthesis. For example, a low phosphate diet increased circulating calcitriol levels by $58 \%$ in a cohort of healthy men. ${ }^{57}$ How serum phosphate affects calcitriol levels in patients without CKD is unclear and it may be through a mechanism unrelated to FGF-23. Further studies are needed in order to elucidate whether phosphate results in increased CVD through a mechanism that involves vitamin D.

\section{Phosphate and FGF-23}

Provocative new findings have shown associations of higher serum FGF-23 levels with allcause mortality and CVD among patients with and without CKD independent of serum phosphate levels and estimated kidney function. ${ }^{13,58-60}$ Possible mechanisms to explain these associations are unknown; it is unclear if FGF-23 has direct toxic effects or if it is merely a marker of the total phosphorus and/or vascular disease burden. Importantly, FGF-23 requires the co-factor klotho to bind with its receptor, so direct effects of FGF-23 are believed to be limited to klotho expressing cells in the kidney, parathyroid glands, and 
brain. In a recent study of uremic mice fed a high phosphate diet, elevated FGF-23 levels, not elevated serum phosphate levels, were associated with extensive arterial-medial calcifications. ${ }^{54} \mathrm{~A}$ recent cohort study of elderly adults found higher FGF-23 levels to independently associate with impaired vasoreactivity and increased arterial stiffness among individuals with apparently normal kidney function. ${ }^{58}$ Exploring the mechanisms by which phosphate might induce CVD is an exciting area of research in which FGF-23 and/or calcitriol may turn out to play a significant role.

\section{Recommendations for treatment of serum phosphate in CKD}

The Kidney Disease Improving Global Outcomes (KDIGO) Clinical Practice Guidelines for CKD-Mineral and Bone Disorders recommend that serum phosphate levels be maintained within the normal range for patients with CKD stage 3-5 who are not yet on dialysis. ${ }^{61} \mathrm{In}$ dialysis patients, KDIGO recommends lowering serum phosphate levels towards the normal range. ${ }^{61}$ Currently, there is no evidence that lowering serum phosphate within a target range improves clinical outcomes. KDIGO recommendations are therefore based on observational data showing associations of higher serum phosphate concentrations with poor outcomes and increased mortality and biologic plausibility from in-vitro and animal models. Despite the lack of randomized trial data, the KDIGO recommendation is to lower serum phosphate in CKD patients using phosphate binders and by limiting dietary intake of phosphorus. The current recommendations are to initiate treatment once serum phosphate levels exceed the normal range. However, there is evidence that even serum phosphate levels within the normal range are associated with adverse patient outcomes and thus waiting for patients to develop overt hyperphosphatemia may not be the correct approach. Alternative biomarkers, such as FGF-23 or the urinary fractional excretion of phosphate, are therefore needed for early diagnosis and possible treatment of disordered phosphorus metabolism before endorgan damage occurs.

Observational data that evaluate phosphate binder treatment in relation to clinical outcomes are limited. A recent prospective observational study evaluated 1-year mortality in 8610 incident dialysis patients who were matched by their propensity to receive a phosphate binder. ${ }^{62}$ Treatment with any phosphorus binder during the first 90 days of dialysis was independently associated with lower all-cause mortality compared to no treatment independent of serum phosphate levels. Randomized clinical trials of phosphate binders have been limited to the comparison of different types of binders without a necessary placebo group, and generally reflect the marketing strategies of the respective manufacturers. For example, the Dialysis Clinical Outcomes Revisited (DCOR) ${ }^{63}$ study randomized 2,103 prevalent dialysis patients to sevelamer or a calcium- based phosphate binder and found no significant differences in all-cause or cause-specific mortality rates (HR for all-cause mortality $0.93,95 \%$ CI $0.79-1.10$; log-rank $P=0.40$ ). In contrast, the Renagel in New Dialysis (RIND) ${ }^{64}$ trial of 127 incident dialysis patients found an increased risk of mortality with calcium-based binders compared to sevelamer after 44 months of follow-up. Nonetheless, only placebo controlled randomized trials can determine whether phosphate binders improve clinical outcomes for patients who have chronic kidney disease. 
Other randomized trials have compared calcium-based versus non-calcium based binders among CKD patients using coronary calcification scores as a surrogate endpoint. Two of these trials in dialysis patients found that the use of sevelamer, in comparison to calciumbased binders, decreased progression of arterial calcifications. ${ }^{65,66}$ Similar findings were reported in a trial involving patients with pre-dialysis CKD. ${ }^{67}$ However, two other recent randomized controlled trials found similar rates of progression of arterial calcification in patients receiving sevelamer and calcium acetate. ${ }^{68,69}$ There have not been any studies comparing the effect of lanthanum carbonate to calcium-based binders or sevelamer on arterial calcifications. Thus, currently there is insufficient evidence to recommend one binder over another. KDIGO recommends that therapy should be individualized to each patient taking into account stage of $\mathrm{CKD}$, presence of other components of mineral-bone disease, use of other medications and side-effect profiles. The Work Group does recommend limiting the dose of calcium-based binders in patients with persistent or recurrent hypercalcemia, adynamic bone disease, arterial calcifications and/or if serum PTH levels are consistently low. ${ }^{61}$ Furthermore, they recommend limiting the long-term use of aluminum based binders in dialysis patients to prevent aluminum intoxication. ${ }^{61}$ Randomized controlled trials are desperately needed in order to guide treatment and hopefully improve outcomes.

\section{Conclusion}

Higher serum phosphate levels consistently associate with cardiovascular disease and death among patients with and without chronic kidney disease. Associations are independent of co-morbid conditions and are supported by biologic plausibility from experimental models. Potential mechanisms by which serum phosphate may cause CVD might involve vascular calcification and/or modulation of key endocrine systems. Given the lack of randomized trial data, current recommendations are to attempt to maintain serum phosphate concentrations near or within the normal laboratory range and the choice of binder should be individualized for each patient. Hence, due to increasing prevalence of CKD in the population, escalating rates of associated cardiovascular morbidity and mortality, and the high costs of treatment, placebo-controlled randomized trials are urgently needed to determine whether phosphate binders can reduce the burden of CVD in the population.

\section{References}

1. Weisinger JR, Bellorín-Font E. Magnesium and phosphorus. Lancet. 1998; 352(9125):391-396. [PubMed: 9717944]

2. Meleti Z, Shapiro IM, Adams CS. Inorganic phosphate induces apoptosis of osteoblast-like cells in culture. Bone. 2000; 27(3):359-366. [PubMed: 10962346]

3. Slatopolosky E, Brown A, Dusso A. Pathogenesis of secondary hyperparathyroidism. Kidney Int Suppl. 1999; 73:S14-19. [PubMed: 10633458]

4. Tonelli M, Sacks F, Pfeffer M, Gao Z, Curhan G. Relation between serum phosphate level and cardiovascular event rate in people with coronary disease. Circulation. 2005; 112:2627-2633. [PubMed: 16246962]

5. Dhingra R, Sullivan LM, Fox CS, Wang TJ, D'Agostino RB Sr, Gaziano JM, Vasan RS. Relations of serum phosphorus and calcium levels to the incidence of cardiovascular disease in the community. Arch Intern Med. 2007; 167:879-885. [PubMed: 17502528] 
6. Chonchol M, Dale R, Schrier RW, Estacio R. Serum phosphorus and cardiovascular mortality in type 2 diabetes. Am J Med. 2009; 122:380-386. [PubMed: 19332233]

7. Kestenbaum B, Sampson JN, Rudser KD, Patterson DJ, Seliger SL, Young B, Sherrard DJ, Andress DL. Serum phosphate levels and mortality risk among people with chronic kidney disease. J Am Soc Nephrol. 2005; 16:520-528. [PubMed: 15615819]

8. Block GA, Hulbert-Shearon TE, Levin NW, Port FK. Association of serum phosphorus and calcium $\mathrm{x}$ phosphate product with mortality risk in chronic hemodialysis patients: a national study. Am J Kidney Dis. 1998; 31:607-617. [PubMed: 9531176]

9. Ganesh SK, Stack AG, Levin NW, Hulbert-Shearon T, Port FK. Association of elevated serum $\mathrm{PO}(4), \mathrm{Ca} \times \mathrm{PO}(4)$ product, and parathyroid hormone with cardiac mortality risk in chronic hemodialysis patients. J Am Soc Nephrol. 2001; 12:2131-2138. 2001. [PubMed: 11562412]

10. Drueke, T.; Lacour, B. Disorder of Calcium, Phosphate, and Magnesium Metabolism.. In: Feehally, J.; Floege, J.; Johnson, R., editors. Comprehensive Clinical Nephrology. 3rd Edition. Mosby Elsevier; Philadelphia, PA: 2007. p. 123-140.

11. Wilz DR, Gray RW, Dominguez JH, Lemann J Jr. Plasma 1,25(OH)2-vitamin D concentrations and net intestinal calcium, phosphate and magnesium absorption in humans. Am J Clin Nutr. 1979; 32(10):2052-2060. [PubMed: 484524]

12. Stubbs J, Liu S, Quarles LD. Role of fibroblast growth factor 23 in phosphate homeostasis and pathogenesis of disordered mineral metabolism in chronic kidney disease. Semin Dial. 2007; 20(4):302-308. [PubMed: 17635819]

13. Gutierrez OM, Mannstadt M, Isakova T, et al. Fibroblast growth factor 23 and mortality among patients undergoing hemodialysis. N Engl J Med. 2008; 359(6):584-592. [PubMed: 18687639]

14. Isakova T, Gutierrez OM, Smith K, et al. Pilot study of dietary phosphorus restriction and phosphorus binders to target fibroblast growth factor 23 in patients with chronic kidney disease. Nephrol Dial Transplant. Jul 14.2010 epub ahead of print.

15. Blacher J, Asmar R, Djane S, London GM, Safar ME. Aortic pulse wave velocity as a marker of cardiovascular risk in hypertensive patients. Hypertension. 1999; 33(5):1111-1117. [PubMed: 10334796]

16. Hollander M, Hak AE, Koudstaal PJ, et al. Comparison between measures of atherosclerosis and risk of stroke: the Rotterdam Study. Stroke. 2003; 34(10):2367-2372. [PubMed: 12958327]

17. Detrano R, Guerci AD, Carr JJ, et al. Coronary calcium as a predictor of coronary events in four racial or ethnic groups. N Engl J Med. 2008; 358:1336-1345. [PubMed: 18367736]

18. Olson JC, Edmundowicz D, Becker DJ, Kuller LH, Orchard TJ. Coronary calcium in adults with type 1 diabetes: a stronger correlate of clinical coronary artery disease in men than in women. Diabetes. 2000; 49:1571-1578. [PubMed: 10969842]

19. London GM, Guerin AP, Marchais SJ, Metivier F, Pannier B, Adda H. Arterial media calcification in end-stage renal disease: impact on all-cause and cardiovascular mortality. Nephrol Dial Transplant. 2003; 18:1731-1740. [PubMed: 12937218]

20. Klassen PS, Lowrie EG, Reddan DN, et al. Association between pulse pressure and mortality in patients undergoing maintenance hemodialysis. JAMA. 2002; 287:1548-1555. [PubMed: 11911757]

21. Verberckmoes SC, Persy V, Behets GJ, et al. Uremia-related vascular calcification: more than apatite deposition. Kidney Int. 2007; 71:298-303. [PubMed: 17149373]

22. Hunt JL, Fairman R, Mitchell ME, et al. Bone formation in carotid plaques: a clinicopathological study. Stroke. 2002; 33:1214-1219. [PubMed: 11988593]

23. Edmonds ME, Morrison N, Laws JW, Watkins PJ. Medial arterial calcification and diabetic neuropathy. Br Med J (Clin Res Ed). 1982; 284:928-930.

24. Micheletti RG, Fishbein GA, Currier JS, Fishbein MC. Monckeberg sclerosis revisited: a clarification of the histologic definition of Monckeberg sclerosis. Arch Pathol Lab Med. 2008; 132:43-47. [PubMed: 18181672]

25. Goodman WG, Goldin J, Kuizon BD, et al. Coronary-artery calcification in young adults with endstage renal disease who are undergoing dialysis. N Engl J Med. 2000; 342:1478-1483. [PubMed: 10816185] 
26. Adeney KL, Siscovick DS, Ix JH, et al. Association of serum phosphate with vascular and valvular calcification in moderate CKD. J Am Soc Nephrol. 2009; 20:381-387. [PubMed: 19073826]

27. Ix JH, De Boer IH, Peralta CA, et al. Serum phosphorus concentrations and arterial stiffness among individuals with normal kidney function to moderate kidney disease in MESA. Clin J Am soc Nephrol. 2009; 4:609-615. [PubMed: 19211667]

28. Foley RN, Collins AJ, Herzog CA, Ishani A, Kalra PA. Serum phosphorus levels associate with coronary atherosclerosis in young adults. J Am Soc Nephrol. 2009; 20:397-404. [PubMed: 18987306]

29. Kendrick J, Ix JH, Targher G, Smits G, Chonchol M. Relation of serum phosphorus levels to ankle brachial pressure index (from the Third National Health and Nutrition Examination Survey). Am J Cardiol. 2010

30. Levy D, Garrison RJ, Savage DD, Kannel WB, Castelli WP. Prognostic implications of echocardiographically determined left ventricular mass in the Framingham Heart Study. N Engl J Med. 1990; 322:1561-1566. [PubMed: 2139921]

31. Levin A. Clinical epidemiology of cardiovascular disease in chronic kidney disease prior to dialysis. Semin Dial. 2003; 16:101-105. [PubMed: 12641872]

32. Silberberg JS, Barre PE, Prichard SS, Sniderman AD. Impact of left ventricular hypertrophy on survival in end-stage renal disease. Kidney Int. 1989; 36:286-290. [PubMed: 2528654]

33. Strozecki P, Adamowicz A, Nartowicz E, Odrowaz-Sypniewska G, Wiodarczyk Z, Manitius J. Parathormone, calcium, phosphorus, and left ventricular structure and function in normotensive hemodialysis patients. Ren Fail. 2001; 23:115-126. [PubMed: 11256521]

34. Galetta F, Cupisti A, Franzoni F, et al. Changes in heart rate variability in chronic uremic patients during ultrafiltration and hemodialysis. Blood Purif. 2001; 19:395-400. [PubMed: 11574736]

35. Culleton BF, Walsh M, Karenbach SW, et al. Effect of frequent nocturnal hemodialysis vs conventional hemodialysis on left ventricular mass and quality of life: a randomized controlled trial. JAMA. 2007; 298:1291-1299. [PubMed: 17878421]

36. Slinin Y, Foley RN, Collins AJ. Calcium, phosphorus, parathyroid hormone and cardiovascular disease in hemodialysis patients. The USRDS waves 1,3, and 4 study. J Am Soc Nephrol. 2005; 16:1788-1793. [PubMed: 15814832]

37. Block GA, Klassen PS, Lazarus JM, Ofsthun N, Lowrie EG, Chertow GM. Mineral metabolism, mortality, and morbidity in hemodialysis patients. J Am Soc Nephrol. 2004; 15:2208-2218. [PubMed: 15284307]

38. Foley RN, Collins AJ, Ishani A, Kalra PA. Calcium-phosphate levels and cardiovascular disease in community-swelling adults: The Atherosclerosis Risk in Communities (ARIC) Study. Am Heart J. 2008; 156:556-563. [PubMed: 18760141]

39. Kalantar-Zadeh K, Kuwae N, Regidor DL, et al. Survival predictability of time-varying indicators of bone disease in maintenance hemodialysis patients. Kidney Int. 2006; 70:771-780. [PubMed: 16820797]

40. Young EW, Albert JM, Satayathum S, et al. Predictors and consequences of altered mineral metabolism: the Dialysis Outcomes and Practice Patterns Study. Kidney Int. 2005; 67:1179-1187. [PubMed: 15698460]

41. Voormolen N, Noordzij M, Grootendorst DC, et al. High plasma phosphate is a risk factor for decline in renal function and mortality in pre-dialysis patients. Nephrol Dial Transplant. 2007; 22:2909-2916. [PubMed: 17517792]

42. Bini A, Mann KG, Kudryk BJ, Schoen FJ. Noncollagenous bone matrix proteins, calcification, and thrombosis in carotid artery atherosclerosis. Arterioscler Thromb Vasc Biol. 1999; 19:1852-1861. [PubMed: 10446063]

43. Luo G, Ducy P, McKee MD, Pinero GJ, Loyer E, Behringer RR, Karsenty G. Spontaneous calcification of arteries and cartilage in mice lacking matrix GLA protein. Nature. 1997; 386:7881. [PubMed: 9052783]

44. Shanahan CM, Cary NR, Salisbury JR, Proudfoot D, Weissberg PL, Edmonds ME. Medial localization of mineralization-regulating proteins in association with Mönckeberg's sclerosis: evidence for smooth muscle cell-mediated vascular calcification. Circulation. 1999; 100:21682176. [PubMed: 10571976] 
45. Tyson KL, Reynolds JL, McNair R, Zhang Q, Weissberg PL, Shanahan CM. Osteo/chondrocytic transcription factors and their target genes exhibit distinct patterns of expression in human arterial calcification. Arterioscler Thromb Vasc Biol. 2003; 23:489-494. [PubMed: 12615658]

46. Jono S, McKee MD, Murry CE, Shioi A, Nishizawa Y, Mori K, Morii H, Giachelli CM. Phosphate regulation of vascular smooth muscle cell calcification. Circ Res. 2000; 87:E10-17. [PubMed: 11009570]

47. Jono S, Mckee MD, Murry CE, et al. Phosphate regulation of vascular smooth muscle cell calcification. Circ Res. 2000; 87:E10-17. [PubMed: 11009570]

48. Steitz SA, Speer MY, Curinga G, et al. Smooth muscle cell phenotypic transition associated with calcification: upregulation of Cfba1 and downregulation of smooth muscle lineage markers. Circ Res. 2001; 89:1147-1154. [PubMed: 11739279]

49. Giachelli CM. The emerging role of phosphate in vascular calcification. Kidney Int. 2009; 75:890897. [PubMed: 19145240]

50. Sugitani H, Wachi H, Murata H, Sato F, Mecham RP, Seyama Y. Characterization of an in vitro model of calcification in retinal pigmented epithelial cells. J Atheroscler Thromb. 2003; 10:48-56. [PubMed: 12621165]

51. Chen NX, O'Neill KD, Duan D, Moe SM. Phosphorus and uremic serum upregulate osteopontin expression in vascular smooth muscle cells. Kidney Int. 2002; 62:1724-1731. [PubMed: 12371973]

52. Li X, Yang HY, Giachelli CM. Role of the sodium-dependent phosphate cotransporter, Pit-1, in vascular smooth muscle cell calcification. Circ Res. 2006; 98:905-912. [PubMed: 16527991]

53. Mizobuchi M, Finch JL, Martin DR, Slatopolosky E. Differential effects of vitamin D receptor activators on vascular calcification in uremic rats. Kidney Int. 2007; 72:709-715. [PubMed: 17597697]

54. El-Abbadi MM, Pai AS, Leaf EM, et al. Phosphate feeding induces arterial medial calcification in uremic mice: role of serum phosphorus, fibroblast growth factor-23, and osteopontin. Kidney Int. 2009; 75:1297-1307. [PubMed: 19322138]

55. O'Connell TD, Berry JE, Jarvis AK, Somerman MJ, Simpson RU. 1,25-Dihydroxyvitamin D3 regulation of cardiac myocyte proliferation and hypertrophy. Am J Physiol. 1997; 272(4 Pt 2):H1751-1758. [PubMed: 9139959]

56. Li YC, Kong J, Wei M, Chen ZF, Liu SQ, Cao LP. 1,25-Dihydroxyvitamin D(3) is a negative endocrine regulator of the renin-angiotensin system. J Clin Invest. 2002; 110(2):229-238. [PubMed: 12122115]

57. Portale AA, Halloran BP, Morris RC Jr. Physiologic regulation of the serum concentration of 1,25dihydroxyvitamin D by phosphorus in normal men. J Clin Invest. 1989; 83:1494-1499. [PubMed: 2708521]

58. Mirza MA, Larsson A, Lind L, Larsson TE. Circulation fibroblast growth factor-23 is associated with vascular dysfunction in the community. Atherosclerosis. 2009; 205:385-90. [PubMed: 19181315]

59. Hsu HJ, Wu MS. Fibroblast growth factor 23: a possible cause of left ventricular hypertrophy in hemodialysis patients. Am J Med Sci. 2009; 337:116-122. [PubMed: 19214027]

60. Gutierrez O, Januzzi J, Isakova T, et al. Fibroblast growth factor-23 and left ventricular hypertrophy in chronic kidney disease. Circulation. 2009; 119:2545-2552. [PubMed: 19414634]

61. Kidney Disease: Improving Global Outcomes (KDIGO) CKD-MBD Work Group. KDIGO clinical practice guidelines for the diagnosis, evaluation, prevention and treatment of Chronic Kidney Disease-Mineral Bone Disorder (CKD-MBD). Kidney Int Suppl. 2009; (113):S1-130.

62. Isakova T, Gutierrez O, Chang Y, et al. Phosphorus binders and survival on hemodialysis. J Am Soc Nephrol. 2009; 20:388-396. [PubMed: 19092121]

63. Suki WN, Zabaneh R, Cangiano JL, et al. Effects of sevelamer and calcium-based phosphate binders on mortality in hemodialysis patients. Kidney Int. 2007; 72:1130-1137. [PubMed: 17728707]

64. Block GA, Raggi P, Bellasi A, Kooienga L, Spiegel DM. Mortality effect of coronary calcification and phosphate binder choice in incident hemodialysis patients. Kidney Int. 2007; 71:438-441. [PubMed: 17200680] 
65. Chertow GM, Burke SK, Raggi P. Sevelamer attenuates the progression of coronary and aortic calcification in hemodialysis patients. Kidney Int. 2002; 62:245-252. [PubMed: 12081584]

66. Block GA, Spiegel DM, Ehrlich J, et al. Effects of sevelamer and calcium on coronary artery calcification in patients new to hemodialysis. Kidney Int. 2005; 68:1815-1824. [PubMed: 16164659]

67. Russo D, Miranda I, Ruocco C, et al. The progression of coronary artery calcification in predialysis patients on calcium carbonate or sevelamer. Kidney Int. 2007; 72:1255-1261. [PubMed: 17805238]

68. Qunibi W, Moustafa M, Muenz LR, et al. A 1-year randomized trial of calcium acetate versus sevelamer on progression of coronary artery calcification in hemodialysis patients with comparable lipid control: the Calcium Acetate Renagel Evaluation-2 (CARE-2) study. Am J Kidney Dis. 2008; 51:952-965. [PubMed: 18423809]

69. Barreto DV, Barreto Fde C, de Carvalho AB, et al. Phosphate binder impact on bone remodeling and coronary calcification-results from the BRiC Study. Nephron. Clin Pract. 2008; 110:c273283. [PubMed: 19001830] 